\title{
LIBERALISATION OF THE CHINESE ECONOMY: APEC, WTO AND TARIFF REDUCTIONS
}

\section{ZHANG YUNLING}

Significant progress has been made in the liberalisation of the Chinese economy since the late 1970s, a natural result of the reform and opening up of the economy. Gradual integration into the world market has promoted economic development. China's involvement in regional and international organisations is an integral part of this process.

\section{THE PROGRESS OF CHINA'S ECONOMIC LIBERALISATION}

\section{REFORM OF FOREIGN TRADE}

Since 1979, China's foreign trade system has undergone remarkable changes. In 1988, foreign trade companies began to apply the contract management responsibility system. In 1991, export subsidies were abolished and companies were made responsible for their own profits and losses. In 1994, with the merging of the official rate and market rate of the renminbi (RMB) at its core, a single, managed RMB floating rate system based on supply and demand of the market was established. From 1996, the RMB became convertible for the current account.

In 1994, mandatory plans on total import and export volumes, export earnings and import spending of foreign exchange, were relinquished and a system of guiding plans was introduced. A unified tax reimbursement system under central finance was gradually established. In accordance with the principles of efficiency, fairness and openness, favourable conditions were created for public bidding, auction and standardised allocation for the quotas on import and export commodities. Actions have been taken to deregulate export businesses gradually to increase competitiveness. 
Significant progress has been made to increase policy transparency. The Ministry of Foreign Trade and Economic Cooperation of China (MOFTEC) has made public internal standardised documents. The General Office of the State Council issued a circular, 'Reaffirming Relevant Rules and Regulations Regarding the Promulgation of National Foreign Economic and Trade Laws, Rules, Regulations and Policies' in October 1993, which stipulated that only those economic and trade laws, rules, regulations, administrative guidance and policies that have been made public will be implemented. Since 1 October 1993, MOFTEC has openly published such policies. More importantly, in May 1994, the 'Foreign Trade Law' was passed.

Despite these advances, significant efforts must be made before China can build a truly efficient and transparent foreign trade management system. Challenges are now coming from internal competition brought about by foreign producers who sell an increasing proportion of their products within China. With respect to foreign direct investment (FDI), the distinction between domestic and foreign trade is becoming less clear.

\section{LOWERING TARIFFS}

The basic principles in setting China's import tariff rates are that tariff exemption or low tariffs should apply to the necessities that bear on the national economy and the livelihood of the people but cannot be produced domestically or whose production cannot meet demand, like grain (wheat, corn, rice), iron ore and most other mineral ores and raw materials; tariff rates for raw materials are generally lower than those for finished or manufactured products; tariff rates for components of machinery equipment which can be produced domestically or whose quality is sub-standard, are lower than tariffs on final products; and, very high tariffs are levied on manufactured products whose domestic production requires protection.

China has made great progress in lowering tariffs. In 1991, tariffs on 43 commodities were lowered. In April 1992, import adjustment tax levied on a group of important machinery and electronic products and chemical fibre was lifted (the import adjustment tax levied on colour TV sets and cars then was 100 per cent). On 1 October 1992, when a new commodity catalogue system of coordination was adopted in formulating customs rules, the tariff on 225 commodities was lowered.

By the end of 1992, the tariff on 3371 commodities had been lowered, thus decreasing the general level of China's tariffs by 7.3 per cent, to 39.9 per cent.

From 31 December 1993, the tariff rates on 2898 items were lowered, including certain domestically scarce raw materials and mechanical equipment, the supply of which could not meet the demand. Those rates were lowered by 8.8 per cent, thus decreasing the average tariff rate to 36.4 per cent. 
From 1 January 1994, the tariff on sedan cars has been lowered from 220 per cent to 150 per cent, and 180 per cent to 110 per cent-depending on cylinder size-thus further reducing the general level of tariffs to 35.9 per cent.

From 1 April 1996, tariffs on 4994 items began to be lowered, accounting for 76.3 per cent of the total 6350 tariff items. In the Chinese Customs Import and Export Tariff Regulations, the establishment of tariff tax items was readjusted in line with the decision of the Customs Cooperation Council and in light of China's economic conditions. The average tariff rate fell from 35.9 per cent to 23 per cent as a result of the reduction. This represented a 35.9 per cent fall (Kong Fanchang 1996).

From October 1997, the tariff rate fell to 17 per cent. Just under 5000 items were affected by the cut.

China's tariffs are dual rates-a preferential and general tariff are set for each commodity. In addition, in the China Customs Import Tariff Regulations, within-quotas tariff rates and temporary tariff rates are stipulated for certain products.

Preferential tariffs apply to the importation of goods from countries which have mutually beneficial trade agreements with China. Currently, China has signed mutually beneficial trade agreements with 137 countries.

General tariffs apply to the importation of goods from countries that do not have agreements with China. However, under special circumstances and with

Figure 1.1 China's tariff reduction trend (per cent)

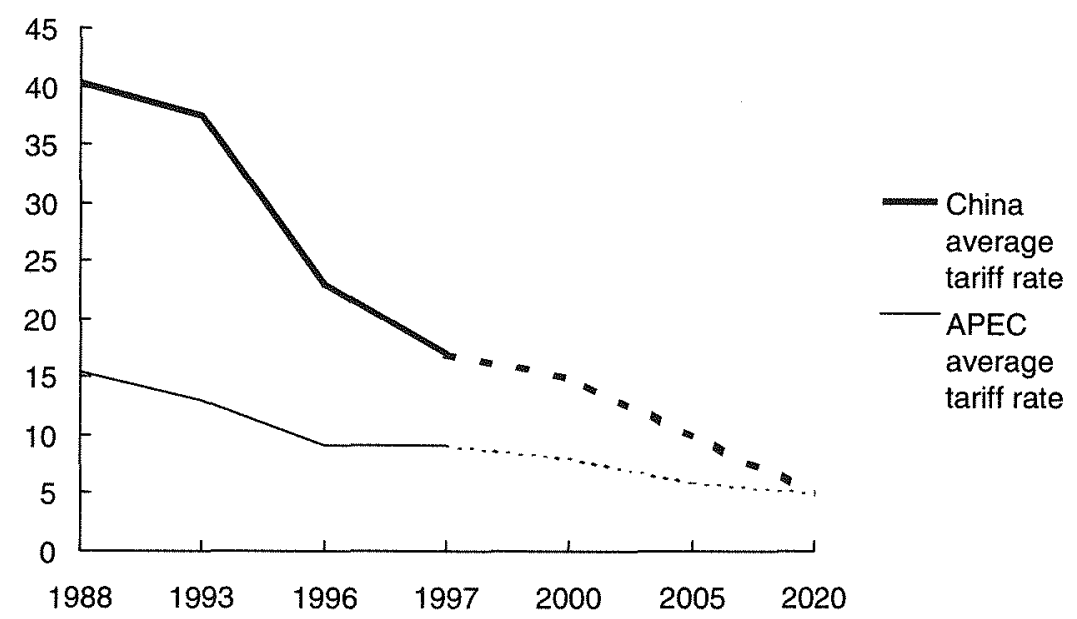

Note: Trend after 1998 does not include new members.

Source: Manila Action Plan for APEC, The Asia Foundation, 1996. 
APEC AND LIBERALISATION OF THE CHINESE ECONOMY

Table 1.1 Impact of $35.9 \%$ to $5 \%$ tariff reduction on the Chinese economy

\begin{tabular}{lrrc}
\hline 1994 & Real value & Simulation & Percentage change \\
\hline GDP* & 45005.8 & 44928.85 & -0.17 \\
Domestic demand & 57059.45 & 57074.57 & 0.03 \\
Import & 12053.4 & 12145.72 & 0.76 \\
Tariff revenue & 330 & 46.31 & -85.97 \\
Labour & 28084 & 28069 & -0.05 \\
GDP** & 29350.51 & 29293.3 & -0.19 \\
Consumer index & 156.6 & 156.24 & -0.23 \\
Note: GDP, 100 Million Yuan; Labor, 10,000; Consumer index, 1990=100. & \\
\multicolumn{4}{|l}{ SCurrent value; ** Constant value. } \\
Source: APEC Policy Research Centre, 1997. Trade Impediments in China, Chinese Academy of Social \\
$\quad$ Sciences:22B.
\end{tabular}

the approval of the Tariff Administration Office of the State Council, preferential tariffs may be applied to the importation of goods from such countries.

Temporary tariffs apply to the importation of part of the production equipment and raw materials.

Special tariffs refer to two categories. The first is the tariff reduction and exemption rendered by administrative authorities to certain special regions, units and individuals in their importation of certain products. The second is the reprisal and counter-reprisal tariffs implemented in international trade disputes. The size and application of special tariffs are often uncertain.

Due to the existence of special tariffs, there is a sharp difference between actual and nominal tariffs in China.

Generally speaking, general tariffs are higher than preferential tariffs, which are higher than within-quotas and temporary tariffs, and special tariffs are uncertain. Nominal tariffs are significantly higher than actual tariffs.

\section{REDUCING NON-TARIFF MEASURES}

Currently, the non-tariff measures in China are predominantly quotas, licence management and administrative management. Before a market economy was introduced, there was a strict approval system implemented on imports into China.

In 1992, a total of 1247 commodities were subject to such measures as import quotas, licences and import controls, and accounted for 20 per cent of total import commodity tariff items.

In 1993, the introduction of 'Management Measures of the Import of Machinery and Electronic Products' and the 'Quota Management of the Import of General Commodities', reduced quota and licence controls over many 
commodities, eliminating all stipulations for import substitute commodities and abolishing the temporary ban and licence control on the import of 34 production assembly lines.

In January 1994, import quotas, licences and administrative approval of 283 commodities -including steel and civil airplanes-were abolished. In June of that year, the import licences and quotas on a further 208 items were eliminated. A year later, quotas and licence controls on 367 goods were abolished. From July the range of import control on machinery and electronic products was further narrowed, reducing tax items from 196 to 160 , and special product tax items from 190 to 119 .

From April 1996, China further eliminated quotas, licences and other import controls on commodities of 176 tax items, accounting for 30 per cent of the total existing commodities under import license control. Currently, commodities under import control measures account for less than 5 per cent of total import tax items (Kong Fanchang 1996).

This represents 384 commodities of a total 6000 tariff items affected by nontariff measures. China only implements unified control over 16 important export commodities such as oil, coal, cotton, grain, maize and tea, while management of other commodities has been decentralised. However, it is argued that China still has too many quotas and licences, and they should be gradually abolished.

As a result, China's foreign trade management system has undergone significant changes. These have included the separation of the functions of administration from those of management, reducing government intervention in enterprises' activities; abolishing mandatory plans regarding export quotas, the obtaining and use of foreign exchange, replacing them with guidance plans under which the state exerts influence on foreign economic activities and trade mainly through economic means such as tax revenue, credit and exchange rates. In the pursuit of transparency, batches of internal documents have been brought into the open and many of them scrapped. An increasing number of companies and enterprises have been granted the right to import and export independently.

However, permission to engage in foreign economic activities and trade needs to be further deregulated. Currently, firms must still gain government approval before they can engage in foreign trade. Few foreign-invested trade companies have been allowed in the foreign trade business. Pressure has been building from outside China to open this field quickly.

China has plans to identify and review all its non-tariff measures and to make public such measures as import quotas, licence and administrative measures, in order to enhance and guarantee the transparency of its non-tariff measures. Meanwhile, it has committed to take concrete steps to reduce gradually or relax its non-tariff measures to bring it in line with international practice. In the intermediate term-from 2001 to 2010 -further cuts will be made. 
A significant effort must be made for China to change from its familiar administrative tools to the rules and measures accepted and recognised internationally. For instance, China has not properly effected laws and regulations pertaining to anti-dumping, countervailing duty, or anti-monopoly. China must go beyond reducing non-tariff measures, to improving the management system to comply with the market system.

Companies and enterprises must also be quick to readjust and adapt to the new situation. Failure to respond quickly may see them pushed out of the market under intense competition. The commitment to reduce non-tariff measures must be made commensurate with the pace of the country's reform and opening up so as to avoid unnecessary losses from excessive pressures on the national economy.

\section{LIBERALISING THE SERVICES SECTOR}

Significant progress has also been made in liberalising China's services sector, widely considered to be the most protected field. Foreign banks and other financial institutions were permitted from the late 1970s, when the reforms began. An experimental step was made in 1982 when China permitted a Hong Kong bank to set up a branch in the Shenzhen Special Economic Zone (SEZ). From 1985, four other SEZs, as well as 13 coastal open cities were allowed to establish branches of foreign banks. A new step was taken in 1992 when China gave permission to a foreign insurance company to start business in Shanghai and Guangzhou. A joint venture was formed between China Construction Bank and Morgan Stanley in 1995. It was the first investment bank allowed to do business in China. Certain foreign banks are allowed to do RMB business in Pudong area, Shanghai, and in Shamen, Fujian Province. Further liberalisation in this areasuch as of security and accounting businesses-continues.

The retail sector is also opening up. Foreign investors in production may sell a certain proportion of their products in China's domestic market according to the agreement. Hainan province and another 10 cities-including Shanghai, Beijing and Guangzhou - are open to a few foreign companies. However, the wholesale sector remains closed to foreign business.

Progress on liberalisation has been made in the transportation sector too. Joint ventures are encouraged in international ocean shipping. Coastal and inland navigation and highway transportation have been permitted limited joint ventures. Airlines are not yet open to foreign companies, but joint ventures may be formed in businesses like plane repairs and airport construction (non-military).

Public communication and specialised communications in China are still closed to foreign companies, although all kinds of investment in communication manufacturing are encouraged. Equipment for communication terminals is allowed to be sold in China under licence. 
Despite these advances, the services sector remains weak in China. More time is needed before it can become competitive.

The pace of liberalisation of the Chinese economy is rapid, but further steps are necessary to make it more open and competitive. China has adapted to the world market and begun to follow internationally accepted trading rules. This has become an irreversible trend.

However, China's market-oriented economic system has yet to be perfected and its enterprises are in the process of transformation. China is very cautious in opening those sectors that are still under transformation and less competitive. For example, as a result of the East Asian financial crisis, China may draw the conclusion that it is dangerous to open the financial sector too quickly.

\section{CHINA'S INVOLVEMENT INAPEC}

China has taken a positive attitude and an active policy approach towards APEC activities. It is well understood that China's major economic relations and interests lie in the Asia Pacific region. The progress of APEC brings significant benefits to China. For example, according to a study done by the Economic Committee of APEC, China may gain as much as US\$14.3 billion- the largest amount of all the APEC members-from the Manila Action Plan for APEC (APEC 1997).

\section{CHINA'S INTEREST IN APEC}

The major role of APEC is to provide a formal mechanism to integrate regional economies and create a more open and cooperative environment for long-term development and prosperity. APEC membership gives China an opportunity to work together with the economies of the Asia Pacific region. APEC is also an important forum where China can voice what it wants and what it opposes.

However, the major benefit for China is APEC's flexibility. China needs a gradual transition as it is a large developing country with very low per capita income, on the difficult road from a planned economic system to a market system. China needs time and room to reform, thus it wants APEC to move unilaterally and gradually. China rejects any efforts to make APEC a strong organisation with mandatory powers and insists that APEC should be an open and flexible forum.

Considering the great diversity of the region, APEC needs to take into account fully the differences in the stages of economic development and socio-political systems of its members in initiating and implementing actions. A flexible approach is essential in achieving this.

APEC has two aims: liberalisation and cooperation. Economic and technical cooperation are underlying features of APEC, strengthened by liberalisation and 
facilitation of trade and investment. They are strong mechanisms to make APEC economies integrated, interdependent and balanced. China has made continuous efforts to promote economic and technical cooperation in APEC.

\section{APEC'S ROLE IN LIBERALISATION}

The dynamics of the Chinese economy are based on an open system. Total imports and exports increased from US $\$ 20.6$ billion in 1978 to US $\$ 340$ billion in 1998. Following increasing integration of the Chinese economy the regional and world markets, it has become open. However, active steps must be taken to reduce tariffs, as well as non-tariff measures.

APEC has no mandate to force its members to reduce trade and investment barriers. Yet the forces of 'peer pressure' can encourage and facilitate them to do so. China's actions in APEC are not just a reflection of this pressure. China uses APEC as an arena to show its willingness and determination to reform

Table 1.2 APEC members gain from Manila Action Plan for APEC

\begin{tabular}{|c|c|c|}
\hline & & \\
\hline Economies/Regions ${ }^{1}$ & Percentage change & $\begin{array}{l}\text { Amount }{ }^{2} \\
\text { billion, 1995) }\end{array}$ \\
\hline Australia & 0.4 & 1.8 \\
\hline Canada & 0.4 & 2.0 \\
\hline Chile & 4.9 & 3.3 \\
\hline China & 2.1 & 14.3 \\
\hline Hong Kong, China & 0,4 & 0.6 \\
\hline Indonesia & 2.4 & 4.9 \\
\hline Japan & 0.1 & 7.2 \\
\hline Korea & 0.8 & 3.8 \\
\hline Malaysia & 7.4 & 6.3 \\
\hline Mexico & 0.7 & 1.7 \\
\hline New Zealand & 1.3 & 0.8 \\
\hline Philippines & 4.3 & 3.2 \\
\hline Singapore & 1.5 & 1.2 \\
\hline Chinese Taipei & 1.3 & 3.3 \\
\hline Thailand & 3.1 & 5.2 \\
\hline USA & 0.1 & 8.9 \\
\hline APEC total & 0.4 & 68.5 \\
\hline Rest of world & 0.0 & 2.4 \\
\hline World MAPA total & 0.2 & 70.9 \\
\hline $\begin{array}{l}\text { 1. Due to data } c c \\
\text { 2. Amounts are b }\end{array}$ & $\begin{array}{l}\text { Brunei Darussalam an } \\
\text { he level of nominal GDP }\end{array}$ & $\begin{array}{l}\text { New Guinea could not be specified. } \\
\text { nomies in } 1995 \text {. }\end{array}$ \\
\hline Source: $\quad$ APEC, 1997. Th & Trade Liberalisation in & nomic Committee, APEC. \\
\hline
\end{tabular}


its economy and integrate itself into the regional and world economy. A significant step was taken in 1995 when President Jiang Zemin announced a 30 per cent tariff reduction on 4000 import items during the Osaka meeting, thus reducing China's average import tariff rate from 35.9 per cent to 23 per cent. A further reduction was announced in September 1997, before the APEC summit meeting in Vancouver, bringing the rate to 17 per cent. Since then, tariffs have been lowered on various goods voluntarily.

The IAP provides a general guideline for China to implement its commitment to the APEC process of trade and investment liberalisation. According to China's IAP submitted to the Manila meeting in 1996, the average tariff rate will be reduced to 15 per cent by 2000,10 per cent by 2010 and 5 per cent by 2020 .

China's tariff level by 2000 may be the highest among the 18 APEC members. China will certainly meet further pressures to speed up the reductions. There is a big gap between nominal and real implemented tariff levels, indicating strong potential for further reductions than those actually planned.

Within 5 years of accession to the WTO, China will gradually carry out the transition from the examination and approval system of foreign trade to the registration system of foreign trade to enterprises. In the long term-from 2012 to 2020 - China will, in compliance with the timetable for non-tariff elimination, completely abolish all non-tariff measures that are inconsistent with the WTO agreement. The problem is there is a big gap between China, the United States and the European Union (EU) in the timetable for reducing non-tariff measures in the negotiation for China's entry to WTO. Due to the difficulties of reform and transition - especially for state-owned enterprises-China wants to have a longer transitional period, on which its counterparts from developed countries do not agree.

As mentioned above, the service sector is the most troublesome. China has planned to increase the number of operational branches established by foreign banks in 24 designated cities and also gradually allow more foreign insurance companies to establish operational branches in places beyond current trial cities during the period 1997-2000. There is to be further relaxation of restrictions on geographical coverage for access to banking business by foreign banks, insurance companies and security companies in the period 2001-10. For transportation, communications and retail and wholesale areas, no clear actions have been elaborated in the medium or long-term. It is obvious that action plans are still very difficult to establish at this early stage of service sector reform. The big challenge is for China to make quick changes once entering the WTO and join the Information and Telecommunication Agreement (ITA) in the near future.

The pressure for standardisation and revision of IAPs in APEC has become strong in order to make implementation more effective and comparable. The IAP process is not static but an ongoing process based on continuous revision. China 
has shown its positive attitude to this process. For example, in 1997, China committed to reduce its tariff rate to 10 per cent by 2005, rather than by 2010 as planned in its IAP presented in Manila in 1996. China will be eager to invite an independent reviewing group to evaluate its progress in implementing the agenda set up by APEC.

Early sectoral voluntary liberalisation is considered an important approach to facilitate the process of trade and investment liberalisation. However, due to the diversity of the APEC economies, it is difficult to reach consensus on how and when to liberalise the 15 sectors. China favours an approach which would start with the easy sectors, and opposes any effort by the United States to enforce early liberalisation.

\section{APEC INVOLVEMENT AND WTO ENTRY}

APEC plays an important role in facilitating China's economic liberalisation. In recent years, China's major tariff reduction measures have been announced at APEC meetings. However, China's actions are not solely APEC-related. They have close ties to China's entry into the WTO.

China began to request the resumption of its GATT membership in 1986. The failure of China's push into GATT made its entry into the WTO more difficult. Lots of working sessions on China's entry into the WTO have been conducted, but China has not yet been admitted entry.

China insists that it has already satisfied the necessary conditions of the WTO as a developing country, while the United States and some other countries argued that China was still far from meeting the basic requirements. The delay has been largely considered a political barrier made by the developed countries, especially by the United States. The debate between the major powers centres on 'entry first' versus 'change first'.

China has about one-fifth of the world's population, is the $10^{\text {th }}$ largest trading nation, and has increasing influence on the world economy. China's accession to the WTO will not just benefit China itself, but also the international trading and economic system. For China, WTO membership will allow it to receive all the benefits of the GATT/WTO agreed market access results, and to export to other WTO members at the rates of duty and levels of commitments negotiated in past and future Rounds. Thus, China will be safeguarded from discriminatory treatment in trade. Equally important, as a member, China will be able to participate in the writing of rules and help to influence the evolution of the multilateral trading system in the next century. China's entry will strengthen the multilateral trading system and enhance the scope of the WTO. China's membership will create more opportunities in terms of access to the Chinese market.

The lengthy negotiations have forced China to revise its commitments again and again in order to meet the requirements of the WTO. This has in fact sped 
up the pace of liberalisation of the Chinese economy. Tariff reductions are one example. China originally only committed to lowering its average tariff rate to 35 per cent within 5 years of joining the WTO, but already the rate stands at 17 per cent, even without accession.

By mid-1999, China had finished bilateral negotiations with many WTO members, including Japan and Australia. This should help China's attempts to enter the WTO. Of course, the major concern is still approval of the settlement with the United States, as well as the settlement with the European Union.

It is true that China likes the APEC way since it is more flexible and unilateral in managing trade and investment liberalisation. However, there is obviously a relationship between China's WTO accession and its actions in APEC - what China has done within APEC has close relation to its entry into the WTO. In fact, the two cannot be separated. On the one hand, China has had to revise its commitments to the WTO continuously under the pressure of the working party for China's accession; on the other, it has to keep pace with APEC's 'WTO plus' initiatives, though it is not a member of the WTO. Strategically, China must limit its actions in APEC so as not to exceed its commitments for WTO accession; otherwise there will be pressures for it to commit more in later negotiations. However, this is very difficult to manage since the two are both ongoing processes. For example, the level of tariff reductions by China after the Osaka meeting was far beyond the earlier commitment made by China for its WTO entry. China stated in 1995 during the second Senior Official Meeting of APEC that it would implement the Uruguay Round (UR) agreements selectively though it was not yet a member of the WTO. In fact, the efforts made by APEC members should speed up the pace of implementing the UR agreement. China also committed to sign the ITA in the near future, likely before its entry into the WTO. It seems that APEC involvement and WTO entry are two forcible means for China to liberalise its economy further. Nevertheless, delay of China's WTO membership is not an ideal strategy to encourage China's reform and opening.

\section{REFERENCES}

APEC, 1996. Manila Action Plan for APEC, The Asia Foundation. , 1997. The Impact of Trade Liberalisation in APEC, Economic Committee, APEC.

APEC Policy Research Centre, Trade Impediments in China, 1997. Chinese Academy of Social Sciences:22B.

Chulsu Kim, 1997. Issues in the negotiations on China's accession to the WTO system, remarks, Lausanne, 20 September.

Jiao Feng Chao Rihui, 1996. On China's Entry into WTO, Development Study, October. 
Kong Fanchang, 1996. Survey on China's Tariff and Non-tariff Barriers, APEC Policy Research Center (APRC), No. 2 (Chinese), Beijing:12.

Long Yongtu, 1997. 'The new measures on China's service sector liberalization', International Business Daily, 8 December.

State Statistical Bureau, 1993-97. Statistical Yearbook of China, China Statistical Publishing House, Beijing.

Zhang Yunling, 1996. China and APEC, APRC, No.2 (English), Beijing. 1997. Early Sectoral Liberalization in APEC: implications to China, APRC, Beijing. 